\title{
RECONSTRUCTING MIGRATION TRAJECTORIES USING ANCIENT DNA
}

\author{
Greger Larson
}

\begin{abstract}
Revealing the temporal and geographic pattern of human and animal dispersal and migration has been a major goal within anthropology, archaeology, and palaeontology. Here, I focus on the use of ancient DNA to delve beneath the migration palimpsests. More specifically, I firstly describe the use of ancient DNA derived from archaeological pig remains as a proxy to understand the initial dispersal of farmers into Europe, the back migration into Anatolia, and the spread of people into the Pacific. I then show how ancient DNA from foxes in the northern and southern hemisphere has been used to understand their dispersal onto islands in the absence of landbridges. These case studies highlight the value of DNA derived from long-dead organisms to detail the pattern and process of ancient dispersals.
\end{abstract}

Keywords: Domestication, pigs, Arctic fox, long-distance dispersal, Lapita dispersal

\section{INTRODUCTION}

Tracing the timing and trajectories of human and animal migratory patterns has been a significant anthropological, archaeological, and palaeontological endeavour. In order to piece together the palimpsest of migrations, scientists have employed a range of proxies including not only genetic signatures and fossil and sub-fossils evidence, but also, in the case of people, linguistics and material culture (see Boivin, Introductory chapter). More recently, the ability to extract and sequence DNA from ancient organismal remains has allowed researchers to directly observe molecular patterns of variation in time and space, thus adding an important temporal perspective to migration-related questions.

Ancient DNA (aDNA) refers to the retrieval and amplification of DNA fragments from organisms that are no longer alive. Like the organism itself, the DNA contained within it begins degrading as soon as it dies. Inevitably, the DNA disappears completely, though the rate at which this occurs can be slow enough to allow for its retrieval and sequencing depending on the preservation conditions (Allentoft et al., 20I2). Because each individual cell of any organism contains a full copy of that individual's entire genome, and several thousand 
copies of the individual's mitochondrial genome, aDNA has been retrieved not just from the obvious remains such as bones, teeth, and tissue, but also from less obvious sources such as hair, coprolites, and even frozen mud, where DNA remained despite the lack of any physical remains (Shapiro and Hofreiter, 20I2). The primary rationale for pursuing an aDNA approach is that it combines the temporal perspective of archaeology with the fine-scale resolution afforded by DNA sequences. This mix of time and resolution allows a wide range of questions to be asked, including those related not only to the organism itself, but also to evolutionary dynamics, climate change, and human and animal migration.

By Io,ooo years ago, humans had reached and settled on all of the continental landmasses except Antarctica, and they were able to do so without the benefit of domestic animals. This large-scale geographic movement demonstrates that people did not require domestic animals in order to travel. Once pigs, sheep, goats, and cows (at least) had been domesticated, however, farmers travelled extensively and moved not only into regions occupied by indigenous huntergatherers, but also onto islands not reached by humans who had travelled without domestic animals.

Because farmers travelled with their livestock, the archaeological remains and genetic sequences of ancient and modern domestic and commensal animals can be used as proxies for establishing the chronology and geography of ancient human migration patterns. This approach has been successfully demonstrated using rats (Matisoo-Smith and Robins, 2004), sheep (Chessa et al., 2009), goats (Fernandez et al., 2006), cows (Edwards et al., 2007b), and pigs (Larson et al., 2007a, 2007b). The first portion of this chapter will focus on the use of pigs as a proxy for human migration. More specifically, I will detail how the temporal and chronological distribution of pig genetic signals has revealed the movement of Near Eastern farmers into Europe, the subsequent migration of European domestic pigs back into Anatolia, and the migration of people who travelled with pigs into the Pacific as far east as Hawai'i.

The second set of examples focuses on questions related to the presence of indigenous foxes and wolves on Iceland and the Falkland Islands respectively. In both cases, these terrestrial mammals arrived on remote islands without the aid of humans. Ancient DNA extracted from sub-fossil remains of both species has been used to address the question of how they were able to successfully traverse sizeable water barriers to arrive on the islands, and showed how the recent lack of sea ice in the northern and southern oceans has prevented any additional migratory events.

It is important to mention two additional points. Firstly, the case studies that I highlight within both sets of examples below are mostly, but not exclusively, drawn from my own work. Secondly, though I address issues related to human migration, I do so by using animal proxies, and none of the examples below make use of aDNA derived from humans themselves. 


\section{THE MIGRATION OF FARMERS INTO EUROPE}

Wild boar were domesticated independently in both the Near East (Ervynck et al., 200I) and in East Asia (Cucchi et al., 20 Io). European wild boar may have been domesticated independently, or they may have been incorporated into domestic stocks introduced from the Near East (Albarella et al., 2006b, Larson et al., 2007a). Unlike sheep and goats, whose wild ancestors were confined to a small geographic region in the Near East, the natural range of the wild boar covers most of Eurasia and as a result of this natural migratory ability, it is difficult to ascertain where wild boar were domesticated on the basis of geography alone. For sheep and goat, remains found associated with archaeological contexts in Europe must be domestic (Clutton-Brock, I999), and as a result, the presence of these two species provide a suggestive marker of the presence of farmers whose ancestors migrated from the Near East (see also Zeder, this volume). Given the geographic distribution of wild boar, and the size variability within wild populations across Eurasia (Albarella et al., 2009), archaeologists are unable to confidently assign a status to Sus remains, and thus the presence of pig remains on their own cannot be associated with Near Eastern farmers.

Traditionally, archaeologists have lacked the ability to unambiguously ascertain differences between geographically differentiated wild boar populations. Armed with the resolution afforded by DNA sequences, however, modern genetic studies have identified numerous geographically isolated populations of wild boar that possess distinct genetic signatures. This phylogeographic structure has revealed the presence of approximately twenty genetic groupings of wild boar, though the relationships between those groupings are uncertain (Giuffra et al., 2000; Larson et al., 2005, 2010). One surprising finding of these studies was a lack of a shared genetic affinity between European domestic pigs and Near Eastern wild boar. The phylogeographic patterns insinuated that wild boar from continental Europe are significantly different from those in Anatolia and the Near East. The zooarchaeological evidence, meanwhile, clearly revealed that pigs were first domesticated in the Near East before they were later introduced into Europe during the Neolithic (Ervynck et al., 200I). Assuming that the biogeographic boundary between European and Near Eastern wild boar along the Bosporus Straight was in place before pigs were domesticated, the reasonable assumption was that the first pigs brought into Europe did not share a genetic signature with European wild boar.

The evidence from modern European domestic breeds showed that they clustered not with Near Eastern, but with European wild boar, a result that suggested that the first pigs introduced by Neolithic farmers had been replaced by European pigs maternally descended from European wild boar. A recent study demonstrated that when hybridisation occurs, incoming populations acquire the mitochondrial signatures of the local population at a much greater 
rate than the opposite circumstance (Currat et al., 2008). This may explain why modern European domestic pigs share a mitochondrial affinity with European wild boar despite the fact that there is little archaeological evidence for the independent domestication of European wild boar.

Having established a plausible rationale for this scenario, the narrative rests on the assumption that the natural geographic ranges of wild boar possessing Near Eastern and European signatures have remained static since the beginning of the Holocene. If the European genetic signature was present within Near Eastern wild boar populations, then Near Eastern farmers could have domesticated this lineage and neither a secondary independent domestication in Europe nor hybridisation would be necessary to explain the modern pattern.

At least three different studies (Giuffra et al., 2000; Larson et al., 2005; Ramírez et al., 2009) have found what are considered to be European haplotypes (admittedly at low frequencies) in Near Eastern wild boar. This pattern led some authors to suggest that the robust phylogeographic structure was not as dichotomous as initially proposed (Larson et al., 2007a). Ramírez et al. (2009) suggested that any inconsistencies within the phylogeographic pattern could be the result of natural admixture of wild boar populations, which would therefore not require human-mediated translocation of domestic pigs that subsequently became feral, as has been previously suggested (Larson et al., 2005, 2007a). Ramírez et al. (2009) supported their argument with a nuclear microsatellite analysis, the results of which demonstrated that though the European, Near and Middle Eastern, and North African wild boar mitochondrial haplotype frequencies are significantly different, using nuclear DNA, the populations cluster into a single group. They argued that since mitochondrial DNA is more prone to extinction due to genetic drift, the observed haplotype frequencies in modern populations could be due to more recent demographic circumstances. Because domestic pigs can readily become feral (Albarella et al., 2006a), ancient introgression, as suggested by Larson et al. (2007a), could not be ruled out as the cause of the observed nuclear and mitochondrial discrepancies within the phylogeographic structure.

A perspective that only incorporated modern DNA would be incapable of resolving this issue. The analysis of aDNA extracted from archaeological remains, however, has become a powerful tool in domestication and migration studies. Though modern DNA analyses possess greater resolution than is typically possible through traditional archaeological and metrical approaches, they lack a temporal perspective, thereby restricting their ability to shed light onto ancient genetic patterns. Given the complex history of pig domestication, and the inability of modern DNA studies to support competing historical hypotheses, aDNA studies of archaeological material are the best means to resolve questions such as those discussed above. 
As mentioned previously, the modern genetic understanding of Near Eastern and European pig domestication rests on the assumption of temporally consistent phylogeographic patterns. By extracting DNA from archaeological material from the Near East to Western Europe, and from Io,ooo years ago to the present, Larson et al. (2007a) directly tested pig domestication hypotheses and revealed the temporal and geographic pattern of pig haplotypes (Figure IO.I).

Once an organisms dies, the DNA within it degrades through time. The rate of that degradation is determined by numerous factors, but tends to be faster in hotter climates and in lower latitudes (Binladen et al., 2006; Allentoft et al., 2OI2). In order to maximise the number of samples that could be successfully studied, Larson et al. (2007a) identified a short ( $~ 80$ base pair) fragment that contained sufficient single nucleotide polymorphisms to confidently assign any sample as having been derived from either a Near Eastern or European lineage. Still, the hotter climates of the Near East meant that the number of archaeological bones that retained amplifiable DNA fragments was reduced, thus limiting the ability of aDNA researchers to compare the DNA of the earliest domestic pigs with those of their European counterparts (Edwards et al., 2007a). Despite this, the preservation of bones from Mesolithic, Neolithic, and later contexts throughout Europe was sufficient to build up a picture of the shifting patterns of haplotypes from wild and domestic pigs across Europe (Larson et al., 2007a).

The aDNA evidence firstly demonstrated that no wild boar in Europe dated to a time before the arrival of the Neolithic possessed Near Eastern haplotypes. In fact, the only Mesolithic pigs that did possess a Near Eastern affinity were from the Crimea, suggesting that the Bosporus strait acted as a biogeographic boundary at least as far back as the beginning of the Holocene. This geographic split between the genetic signatures of wild boar on each side of the boundary then allowed Larson et al. (2007a) to directly assess whether the first domestic pigs in Europe were brought in from the Near East, or were domesticated from wild boar indigenous to Europe. In several Romanian sites as well as the German site of Eilsleben, every pig identified as domestic using morphometric criteria possessed Near Eastern haplotypes, and all wild boar samples possessed a European genetic signature. This pattern also held at the Neolithic site of Bercy in France (dated to $\sim_{4}, 000$ cal BC), with the exception of a single domestic pig that possessed a European haplotype (Figure IO.I).

All domestic pigs sampled across Europe younger than this site, however, possessed European mitochondrial signatures, demonstrating that at least on the continent, the domestic pigs originally introduced from the Near East had been replaced by pigs maternally descended from European wild boar. The only exceptions were individual medieval and modern pigs from Corsica that retained a Near Eastern maternal genetic affinity, suggesting that they retain the mitochondrial legacy of the first pigs introduced during the Neolithic. 


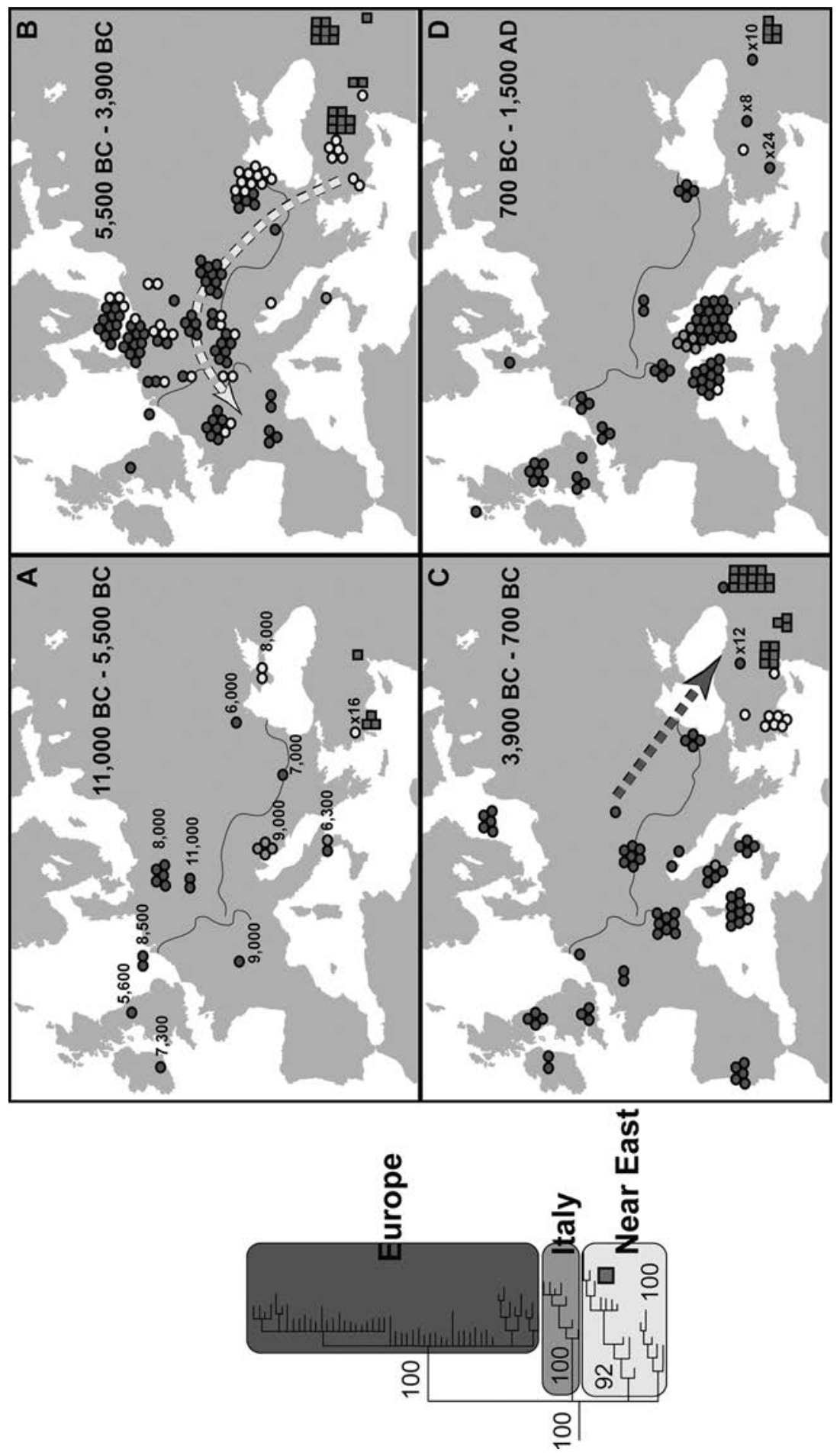

Figure I0.I A map depicting the geographic distribution of different mitochondrial haplotypes across Western Eurasia in four successive chronological bins. The phylogeographic tree to the left depicts the relationship between the main clades 
Intriguingly, the presence of different haplotypes along the purported northern and southern Neolithic routes into Europe seemed to suggest that different lineages of pigs were transported along these trajectories, but the number of samples was too small to conclusively substantiate this potential correlation (Larson et al., 2007a).

\section{PRODIGAL PIGS RETURN TO ANATOLIA}

Though the overall success rate of pigs from the Near East included in the study of ancient European pigs discussed above was relatively low, the few samples that did yield reproducible results demonstrated that the turnover of pigs with Near Eastern mitochondrial haplotypes to those with European haplotypes took place not just in Europe, but in Anatolia as well. This result prompted a larger-scale study of wild and domestic pigs sampled across Anatolia, the Caucasus, and western Iran from the early Neolithic to the Medieval era.

In this study, Ottoni et al. (2013) generated mitochondrial sequences from 393 archaeological wild and domestic pigs from 48 sites and, in addition, analysed 46 archaeological specimens (with known genetic haplotypes) using different methods to assess variations in pig shape and size. Though most of the earliest specimens failed to produce genetic signatures, one specimen excavated from an early Pottery Neolithic layer ( 6800-6500 BC) at Çayönü Tepesi (in Anatolia), representing the final stages of the proposed in situ domestication process (Hongo and Meadow, I998; Ervynck et al., 200I), was successfully sequenced. This individual possessed a haplotype (ArmiT) that was and remains common in eastern Anatolia and Iran, but differs from the haplotype (Y I) predominant in western Anatolia that was later transported into Europe. This result suggests that the first domestic pigs possessed the Armi T haplotype. After they were transported by people to a region where the local wild boar possessed a different signature, the domestic pigs rapidly acquired the novel haplotype. This process happened again after domestic pigs, now with the Y I mitochondrial signature, were transported to Europe.

\section{Caption for Figure I0.I (cont.)}

and haplotypes found in pigs in this region. Each dot on the map corresponds to a single individual that possesses a haplotype from the coloured clades, except in cases where the dot is followed by a number that indicates how many individuals from that location possessed that haplotype. The earliest domestic pigs in Europe were first introduced from Anatolia $\sim 5,500 \mathrm{cal} \mathrm{BC}$, and the first pigs possessing European mitochondrial ancestry were introduced back into Anatolia about I,600 cal BC. A separate Near Eastern haplotype labelled in blue was likely possessed by the first pigs to be domesticated in Eastern Anatolia, but that signature was never introduced to Europe. This image summarises data from three recent publications (Larson et al., 2007a, KrauseKyora et al., 2013; Ottoni et al., 2013). 
Domestic pigs possessing European haplotypes were then reintroduced to Anatolia and they were initially thought to have replaced Near Eastern haployptes in Armenia by 700 BC (Larson et al., 2007a). However, the Ottoni et al. (20I3) study demonstrated that the first AMS-dated pig with European ancestry (haplotype A) appeared nearly I, ooo years prior, in a Late Bronze Age context $(\sim \mathrm{I}, 600-\mathrm{I}, 44 \mathrm{O}$ BC) at Lidar Höyük in Anatolia. In addition, a geometric morphometric analysis of 46 pigs with known genetic signatures revealed significant differences in both molar size $(p<0.01)$ and shape $(p<0.05)$ between European and Near Eastern pigs, suggesting that pigs possessing European mitochondrial DNA (mtDNA) could not have been indigenous to Anatolia, and must have been introduced. Once they arrived, the frequency of pigs with European ancestry increased rapidly from the twelfth century BC, so that by the fifth century AD, domestic pigs exhibiting a Near Eastern genetic signature had nearly disappeared across Anatolia and the southern Caucasus (Ottoni et al., 20I3) (Figure IO.I).

The spatiotemporal pattern of the initial introduction and subsequent dominance of European pigs allowed for the turnover to be assessed in its cultural context. Minoans and Mycenaeans may have initially introduced pigs during the Bronze Age when they colonised the western Anatolian coast from the sixteenth to the twelfth centuries BC, though the general paucity of samples from this region makes it difficult to arrive at firm conclusions. Alternatively, pigs may have bypassed the coast and been imported under the Hittites (Seeher, 2OII), whose kingdom reached from central Anatolia to the northern Levant from the seventeenth to thirteenth centuries BC (Bryce, 2005). Additionally, the lack of pigs possessing European signatures in Bronze Age contexts from sites in Georgia suggests that pigs did not arrive via the Caucasus. And of course, unlike the movement of pigs westwards, it is possible that European domestic pigs arrived into Anatolia primarily as traded livestock rather than with a human demographic movement into the region. Regardless of the exact routes of their arrival, European domestic pigs were deliberately introduced into Anatolia, and within 2,000 years pigs with European mitochondrial lineages had replaced their Near Eastern counterparts.

\section{HUMAN MIGRATION INTO THE PACIFIC}

The human movement into Oceania during the late Holocene was one of the most extensive human dispersals in prehistory (Diamond, 2000; Wilmshurst et al., 20II; Hunt and Lipo, this volume) and is enormously significant because although hunter-gatherers in the region were capable of travelling over water, the remote islands of the Pacific were only reached with domestic animals. Though the ancestors of the Pacific settlers must have begun in East Asia, uncertainties remain regarding the precise geographic origins of modern populations in Melanesia, Micronesia, and 
Polynesia. A variety of scenarios have been suggested based upon the associated material culture, language, and human genetic signatures to explain the movement of Neolithic cultures into Near and Remote Oceania (Bellwood, I998; Green, 2000; Kirch, 2000; Terrell et al., 200I; Hurles et al., 2003; Oppenheimer, 2004; Anderson, 2005; Bellwood and Diamond, 2005). The degree to which the cultural and biological elements used to trace the routes can be used as accurate proxies for human dispersal has been questioned, as has the extent to which these various components were dispersed as a single unit (Hurles et al., 2003). For example, models of the origins of Lapita (the immediate ancestors of the Polynesians and many other Oceanic cultures) that focus on the entire Lapita cultural and ecological package migrating from Taiwan to the Pacific differ significantly from those that identify broader regions and possibly multiple origins of the various cultural components (Donohue and Denham, 20Io; see also Denham, this volume).

Like the western Eurasian examples discussed above, analyses of genetic variation in the domestic and commensal animals that were linked with Neolithic cultures, and that were significant components of human dispersal and exchange networks, can shed light on the origins and routes of the migrating cultures. Pigs, chickens, dogs, and rats were introduced to the islands of Near and Remote Oceania by human settlers, and studies of Pacific rats (Matisoo-Smith and Robins, 2004) and pigs (Allen et al., 200I, Larson et al., 2005) have demonstrated the potential of these taxa to act as reliable proxies for reconstructing patterns of human dispersal into Oceania. A previous genetic study of pigs in the region (Larson et al., 2005) revealed a unique genetic population that the authors termed the 'Pacific Clade'. Pigs that possessed this signature were only found in the Moluccas islands, New Guinea, and several Pacific islands including Hawaii and Vanuatu - places that have never hosted an indigenous population of wild boar (Bellwood and White, 2005). The absence of Pacific Clade haplotypes in any wild or domestic pigs from mainland Asia, or Island Southeast Asia (ISEA) west of the Wallace Line (Larson et al., 2005), however, meant it was not possible to identify the geographic origin of the clade.

Larson et al. (2007b) later investigated the geographic origin of the Pacific Clade and its distribution within ISEA and Near and Remote Oceania by typing mitochondrial control region sequences from more than 200 wild, feral, and domestic pigs from across the region and mainland Southeast Asia, using both museum specimens and archaeological remains from several islands. The resulting phylogenetic tree revealed that all of the pigs in ISEA found west of the Wallace line represented the most basal portion of the tree, suggesting that the genus Sus originated in ISEA. The Pacific Clade pigs, however, clustered with several other clades in East Asia, demonstrating that though this mitochondrial signature is now primarily present east of the 


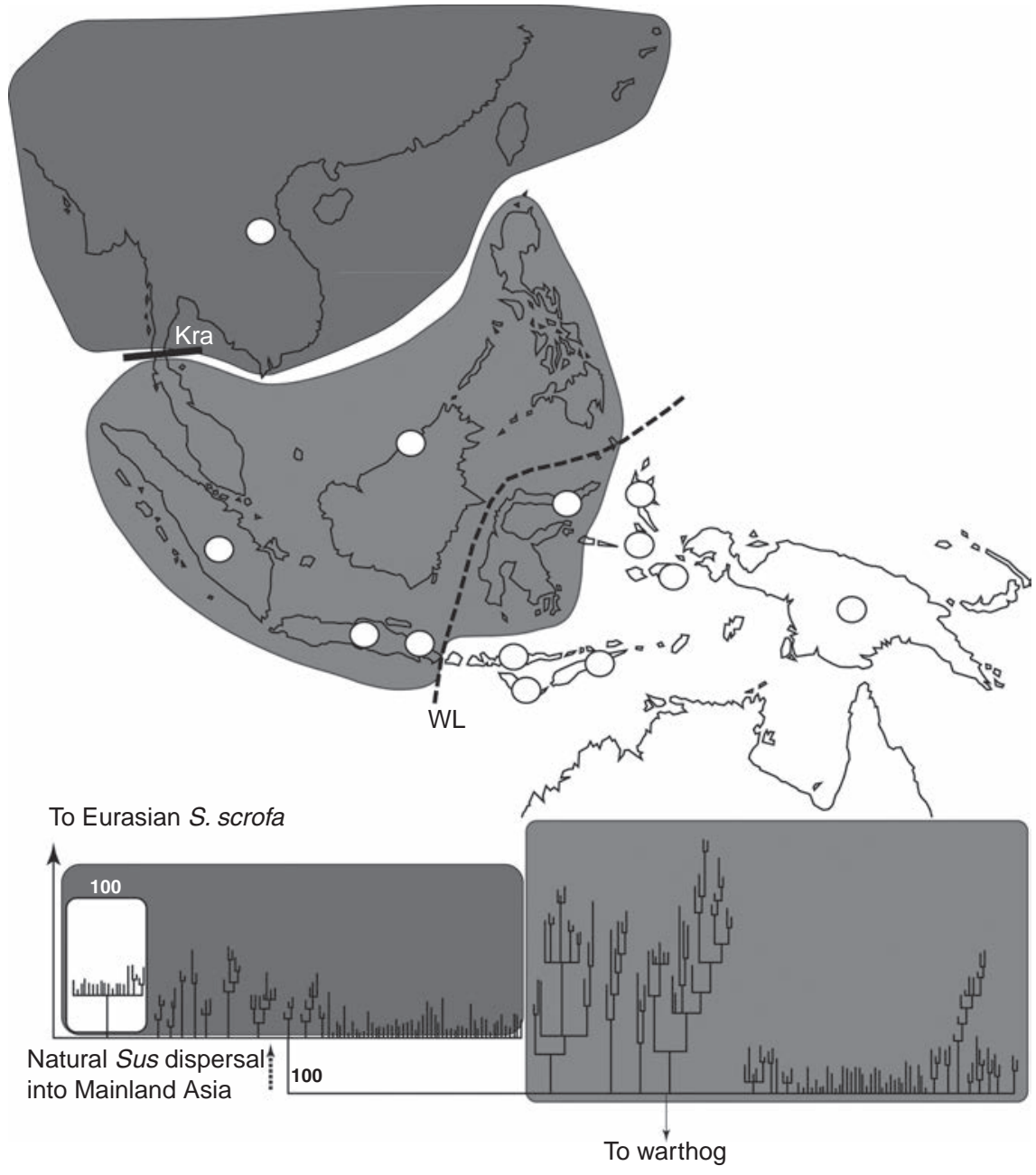

Figure I0.2 A map showing the geographic distribution of pigs possessing haplotypes belonging to three separate clades. Wild boar from Island Southeast Asia are shown in light grey, and those from East Asia are shown in dark grey. The Pacific Clade is coloured in white on the tree and is phylogenetically embedded within the East Asian portion of the tree, indicating that these haplotypes evolved after wild boar migrated into mainland East Asia. The modern distribution of feral and domestic pigs possessing these signatures are shown in white circles. These haplotypes are also found in the Near and Remote Pacific and were almost certainly associated with the initial expansion of people into the Pacific. The black dotted line is the Wallace Line, east of which sits Wallacea to New Guinea. The black solid line shows the location of the Kra Isthmus. This figure is based on information presented in Larson et al. (2007b).

Wallace line, it only arose after wild boar had moved north across the Kra Isthmus in modern Thailand and spread into East Asia (Figure Io.2).

Large-scale genetic typing of pigs throughout East Asia has recently revealed at least five individual wild boar samples whose genetic signatures match those 
of the Pacific Clade (Larson et al., 2010). These specimens, found in Vietnam, Laos, and Yunnan province, China, suggest that the Pacific Clade is likely indigenous to Peninsular Southeast Asia (the area southeast of China). In addition to these individuals, museum samples possessing Pacific Clade haplotypes were also identified in Sumatra and Java and eight islands east of the Wallace line in the Moluccas and Lesser Sunda chains, including New Guinea. Despite additional sampling through ISEA, however, no Pacific Clade pigs have yet been found in either Taiwan or in the Philippine islands, despite the fact that archaeological evidence strongly implies that people travelled with pigs from Taiwan to at least Luzon, the northernmost Philippine island in the archipelago (Piper et al., 2009).

Only the island of Sulawesi in Wallacea (the area between Borneo and New Guinea) hosted endemic populations of Sus scrofa (Morwood et al., 2004). In fact, archaeological investigations on Flores (Morwood et al., 2004), Timor (Glover, I986), and the northern Mollucas (Bellwood and White, 2005) have demonstrated that the first appearance of pigs only occurred in deposits associated with the arrival of the Neolithic 'cultural package'. As a result, the archaeological evidence seems to suggest that a separate population of pigs, unrelated to the Pacific Clade, were brought south from Taiwan to the Philippines. In addition, because the modern Pacific Clade pigs in Wallacea and New Guinea match the signatures found in wild boar from Peninsular Southeast Asia, the evidence suggests that this latter region is where pigs were domesticated before being transported though ISEA (Figure I0.2).

This narrative fits the genetic data, but fails when considering the archaeological record in Peninsular Southeast Asia, where the evidence suggests that that domestic pigs were not present before the end of the fifth millennium BP, when they appear alongside the first evidence of sedentary agriculture (Higham, I975, 2002). This suggests that domestic pigs found in this region were not the result of a domestication process involving local wild boar and that they should not have Pacific Clade haplotypes. In addition, no modern domestic pigs possessing Pacific Clade haplotypes have yet been found north or west of Peninsular Southeast Asia in mainland Asia. These two facts seem to contradict the hypothesis that connects pig populations in Peninsular Southeast Asia with those in the Pacific.

The lack of modern Pacific Clade domestic pigs in Peninsular Southeast Asia could be a consequence of a replacement of native domestics by pigs later introduced from Central China during several possible demographic expansions of agricultural populations into the region. Replacement of mitochondrial lineages has been demonstrated in several domestic animals including chickens in the Pacific (Gongora et al., 2008) and the Near Eastern pigs in Europe discussed above (Larson et al., 2007a). In Southeast Asia, if Pacific Clade domestic pigs were among the first lineages present, they could have been replaced by pigs introduced by several groups, including Austronesian 
speakers expanding through ISEA and parts of the mainland coastal regions (Pawley, 2003), post-Neolithic expansions of Sino-Tibetan speakers (Van Driem, I998; Pawley, 2003), and Austro-Tai or Miao-Yao groups from Southern China (Blench, 2005).

Intriguingly, there is genetic and morphological evidence that people were transporting another suid species (Sus celebensis) within ISEA many thousands of years before the Pacific migrations. A single modern specimen and seven archaeological Liang Bua Cave (on the island of Flores) specimens $(\sim 4,000-7,000$ years old) possessed a unique Sus celebensis haplotype from Sulawesi (Larson, 2007b). There is a long history of animal translocation in ISEA and Island Melanesia (Flannery and White, I99I; Spriggs, I997; Heinsohn, 2003), and since Sus celebensis is endemic only to Sulawesi, its presence on Flores as early as 7,000 BP suggests an early translocation of this species by humans. Independent verification of the distinctiveness (and also probable domesticated origin) of pigs with the Pacific mtDNA signature was demonstrated by morphometric analysis of the lower third molar from the modern and archaeological New Guinea and Flores pigs (Larson, 2007b). Whereas most domestic pigs from the region matched the shape signatures found in domestic pigs, these specimens possessed tooth shapes that clustered with museum samples of Sus celebensis.

Despite the lack of comprehensive sampling, the data thus far support human-mediated dispersals of Sus species not only from Asia into the Pacific, but also within Wallacea (regional species movements also echoed in the botanical data; see Denham, this volume). The archaeological evidence in the northern Philippines (Piper et al., 2009) as well as the genetic evidence from the Lanyu island off the coast of Taiwan (Wu et al., 2007; Luetkemeier et al., 20Io) suggests that people may have migrated with another genetically and regionally distinct domestic pig, even if that subpopulation was not subsequently carried into the Pacific. The different components of the Neolithic cultural complex may therefore have different origins and trajectories to Near Oceania, where they finally coalesced, becoming identifiable as Lapita. Knowing that the pigs may have travelled along a different route than the one traversed by the primary ancestors of Polynesians will help to unravel a complicated migration pattern (Donohue and Denham, 20Io; Wollstein et al., 20Iо; Wilmshurst et al., 20I i; Hunt and Lipo this volume, Denham this volume).

\section{ARCTIC FOX MIGRATION ONTO ICELAND}

Just as aDNA can reveal patterns of human migration when domestic animals are used as proxies for trajectories followed by farmers, sequences from ancient wild specimens can be used to understand migration patterns and, for example, resolve conundrums regarding the timing of the appearance of non-volant 
mammals on islands. By way of illustration, the Arctic fox (Vulpes lagopus) is the only indigenous mammal on Iceland, and though foxes arrived there by crossing Arctic sea ice well before human settlement (Hersteinsson et al., 2007) the population history of the Icelandic Arctic fox prior to the twentieth century is not well understood. In order to determine the extent to which sea ice played a role in fox population connectivity and genetic variation, a recent study (Mellows et al., 20I2) sequenced mitochondrial sequences from seventeen Arctic foxes excavated from two late ninth- to twelfth-century AD archaeological sites in northeast Iceland, both of which predate the Little Ice Age ( $\sim$ sixteenth to nineteenth century).

The Arctic fox has traditionally been considered vermin in Iceland because of its purported role in killing sheep. Fox hunting has been encouraged and legislated since the thirteenth century. The most effective law targeted at the extermination of the Arctic fox was passed in 1957, and by the I970s the population had declined to approximately I,300 individuals (Angerbjörn et al., 2004a). Despite this bottleneck, foxes have rebounded and not only do modern estimates suggest there are now $\sim$ IO, OOO individuals (Hersteinsson, 20IO), but microsatellite data has also been unable to reveal a signature of the I970s bottleneck in the modern population.

High mobility across both land and sea ice is believed to have had an important influence on the distribution and maintenance of genetic diversity of the Arctic fox across its range. These foxes possess a propensity for longdistance migration during periods of nutritional stress (Angerbjörn et al., 2004a, $2004 \mathrm{~b}$ ) and adult foxes of both sexes are known to travel thousands of kilometres in a single year while spending substantial periods on Arctic pack ice (Pamperin et al., 2008; Tarroux et al., 2010). As a result, previous studies using both mitochondrial and microsatellite markers have demonstrated that the presence of sea ice is the most important factor in explaining Arctic fox global population structure (Geffen et al., 2007; Norén et al., 20IO, 20I I). Genetic differentiation between Arctic foxes in North America, North Greenland, and Svalbard is low, suggesting that areas frequently connected by sea ice allow for extensive movement between them, leading to homogenised populations (Carmichael et al., 2007; Norén et al., 2010).

By contrast, islands surrounded by open water year round, such as the Commander Islands, Pribilof Islands, and Iceland, show a distinct pattern of genetic isolation (Geffen et al., 2007). Unlike the other islands, however, Iceland may have been connected to the rest of the Arctic frequently during the last millennium. This likelihood is reflected by the presence of both indigenous mitochondrial haplotypes (II and I2) and haplotypes found across the Arctic $\left(\mathrm{H}_{2}, \mathrm{H}_{5}\right.$, and $\left.\mathrm{H} 8\right)$ that have been observed in specimens from regions across the circumpolar distribution of the Arctic fox (Dalén et al., 2005) (Figure I0.3).

Records dating from the Little Ice Age cooling event ( $\sim$ sixteenth to nineteenth century) (Mann, 2002; Grove, 2003) suggest that grounding of Arctic sea 

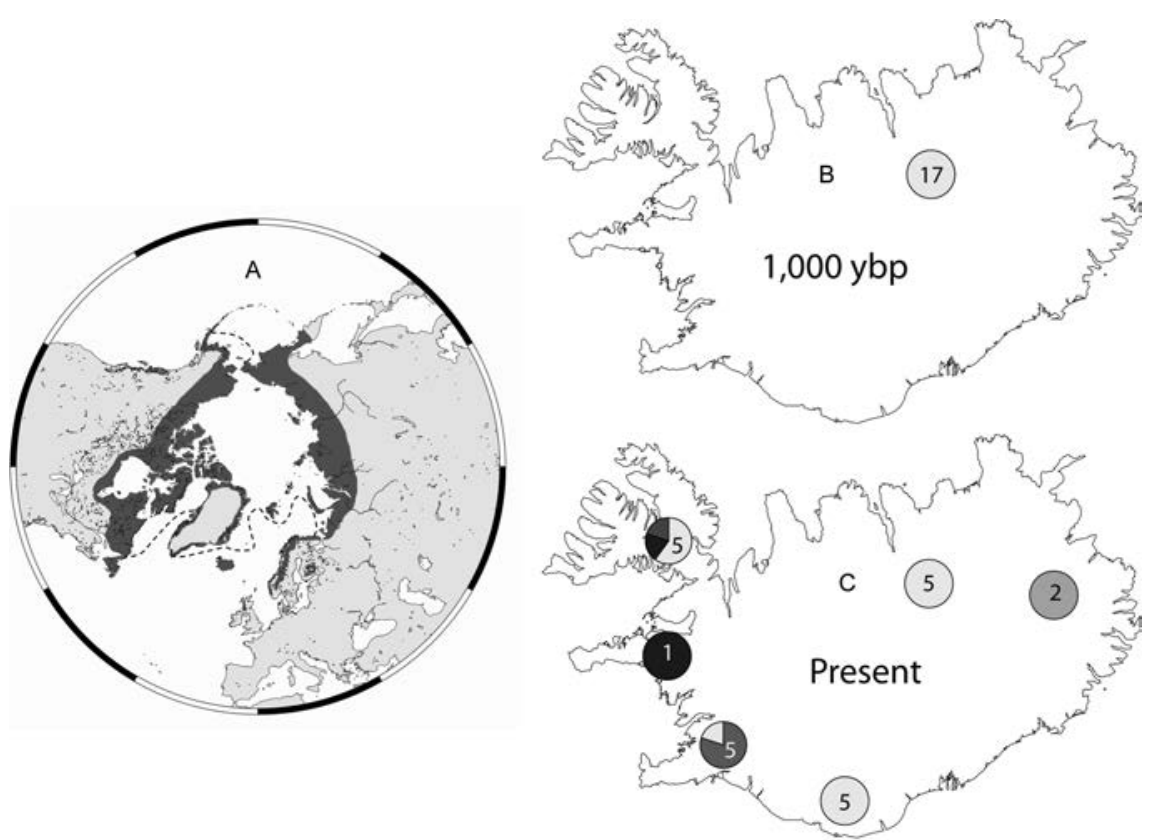

(H2) $\mathrm{H5}$ H8 11 (12)

Figure 10.3 The blue region in Panel A shows the distribution of the Arctic Fox from a polar perspective, and the black line delimits the maximal extent of Arctic sea ice. Iceland is the only landmass not at least occasionally connected to continents via sea ice where Artic foxes are currently indigenous. Panels B and C show the distribution of five different haplotypes I, OOO years ago in the present. Haplotypes beginning with $\mathrm{H}$ are found across the Holarctic and those beginning with I are found only on Iceland. These images are based on figures presented in Mellows et al. (20I2). (A black and white version of this figure will appear in some formats. For the colour version, please refer to the plate section.)

ice on Iceland's northern shore may have been common, thus connecting Iceland and Greenland for several months of the year (Grove, 2003). Such a sea ice bridge may have enabled gene flow into Iceland, resulting in an influx of genetic diversity during the last millennium (Geffen et al., 2007).

The genetic results of the ancient fox samples indicated that the Icelandic fox

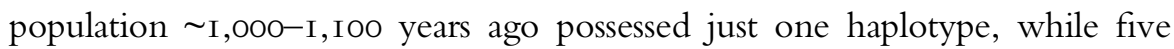
haplotypes are present in the modern population, including three that are found across the Holarctic. There are three possible explanations for this pattern. Firstly, because all of the successfully amplified ancient samples were excavated from two sites in close proximity to each other in northeast Iceland, it is possible that the lack of haplotype variation in the ancient samples is the result of a regionally restricted sample. If foxes on Iceland possessed a strong phylogeographic signature, it is possible that other haplotypes existed in regions outside the Lake Mývatn region. In fact, superficial support for this argument is 
demonstrated by the fact that all five modern fox sequences obtained from this location also possess the same I 2 haplotype found in the ancient population (Figure I0.3).

A study of microsatellite data from Icelandic foxes, however, concluded that nuclear gene flow occurs extensively over Iceland (Norén et al., 2009a). Since Arctic fox dispersal is not sex-biased (Tannerfeldt and Angerbjörn, I996), it is unlikely mtDNA phylogeographic structure would exist when nuclear signatures provide no evidence for it. In addition, a simulation analysis found no significant signature $(p=0.18-0.22)$ of geographic structuring of modern mitochondrial haplotypes. It is therefore unlikely that phylogeographic structuring could be responsible for the observed homogeneity in the ancient samples.

Secondly, recent hybridisation with farmed Arctic foxes may have increased the number of haplotypes. Imported blue foxes have been farmed on Iceland since the I930s, and breeding between escaped farmed foxes with wild individuals has been observed (Hersteinsson et al., I989). In addition, hybridisation between farmed Arctic foxes and their wild counterparts, with ensuing shifts in haplotype frequencies, has also been observed in other regions of the Arctic fox's distribution (Norén et al., 2009b). Because all farmed foxes in Iceland only possess a haplotype that has not been observed in the contemporary wild population (Norén et al., 2005), introgression from farm foxes cannot account for the observed difference between the ancient and modern populations.

The only remaining explanation is sea ice-mediated gene flow from adjacent areas of the Arctic during the Little Ice Age. Sea ice around Iceland was once highly variable and many severe sea ice years were recorded during the late eighteenth and nineteenth centuries (Ogilvie, I99I). The last recorded grounding of sea ice on the shores of Iceland occurred in 1877 , after which sea ice abundance in the North Atlantic declined significantly (Grove, 2003). Such groundings are likely to have been more common during the Little Ice Age, as a result of the increased frequency and severity of cold years. An intermittent sea ice bridge between Greenland and Iceland could have facilitated migration between these regions, a scenario consistent with the dispersal characteristics of the Arctic fox (Tarroux et al., 20Io). In addition, a simulation test suggested that the novel variation observed in the modern sample was likely introduced into Iceland during the second half of the last millennium, as Arctic foxes migrated across a transient sea ice bridge (Mellows et al., 2012).

Overall, the results of this study suggested that a single, indigenous mitochondrial haplotype was already present in Iceland prior to the Little Ice Age. The advent of colder temperatures associated with global cooling led to more frequent sea ice groundings that facilitated Arctic fox migration from Greenland (and perhaps other regions of the Arctic) into Iceland. These immigrants possessed four additional haplotypes that increased in frequency 
until they reached modern proportions. Since incidences of sea ice around Iceland, and the potential for immigration, have decreased during the twentieth century as a result of global warming (Vinnikov et al., I999), the likelihood of new fox haplotypes arriving on Iceland has decreased. As a result, the indigenous population will continue to genetically diverge, thus further differentiating the Icelandic population from their mainland relatives.

\section{THE MIGRATORY ORIGIN OF FALKLAND ISLAND WOLVES}

The story of Icelandic Arctic foxes discussed above contributes to an accumulating body of evidence indicating the importance of sea ice in creating and maintaining the genetic population structure of the species across its Arctic distribution. A similar South American case study involving a South American wolf has recently been addressed in consecutive publications.

The origins of the Falkland Islands wolf (Dusicyon australis) have been a mystery since their initial discovery because, as Darwin noted after he witnessed the animal, the wolf was the largest quadruped that existed on an island so far from a continental coast (Darwin, I839). As a result, both the taxonomic placement of the species and the mode of its arrival on the Falkland Islands have remained unknown. Sadly, the species went extinct in I876, following its most closely related ancestor on the mainland (Dusicyon avus), which went extinct in the mid-Holocene (Berta, I987).

Though previous morphological analyses have been unable to unambiguously answer either where this species arrived from or its taxonomic placement, two recent studies using aDNA approaches on museum and sub-fossil material have had greater success. The first study (Slater et al., 2009) amplified mitochondrial DNA from five museum specimens of the Falkland Islands wolf and determined that the species' closing living relative was the South American Maned wolf (Chrysocyon brachyurus). While intriguing, this result could not resolve how or when the Falkland Island Wolf safely navigated the distance between the continent and the archipelago.

A second study (Austin et al., 20I3) combined these results with sequences obtained from the more closely related (also extinct) mainland wolf, and demonstrated that these two were indeed sister taxa, and only diverged from each other about I6,000 years ago (Figure I0.4). This result immediately eliminated the possibility that humans intentionally introduced the wolf to the islands since they most likely migrated several thousand years before humans arrived in South America. The Falkland Islands currently rest $>300 \mathrm{~km}$ from the Argentine coast. During the Last Glacial Maximum (when the two species split), however, sea levels were I IO $\mathrm{m}$ to I $30 \mathrm{~m}$ lower than at present, meaning the island would have only been $20-30 \mathrm{~km}$ from the shore and the waters between them only Io-30 m deep (Austin et al., 2OI3). Though the authors agree that the foxes could have dispersed by ice, 


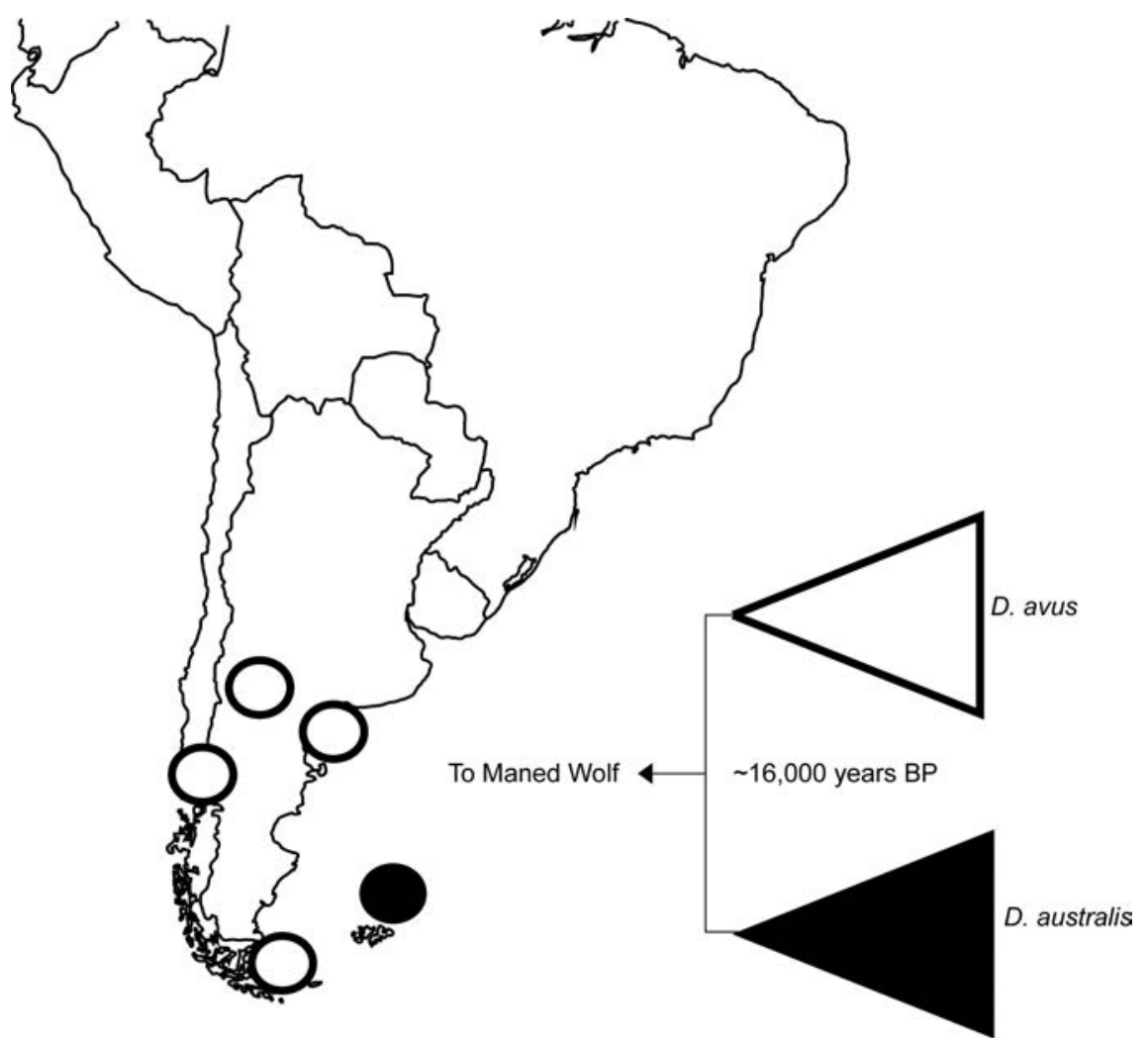

Figure I0.4 A map of South America depicting the location (in black) of the Falkland Islands wolf ( $D$. australis) and where on the continent samples of an extinct relative (D. avus) were sampled (in white). A schematic phylogenetic tree to the right of the map depicts the relationship between the two species and the timing since their proposed divergence based upon $>_{\mathrm{I}, \mathrm{OOO}} \mathrm{bp}$ of mitochondrial DNA. Both the tree and the map have been modified from Austin et al. (2013).

as has been previously suggested (Berta, I987), they contend that given the high latitudes, the marine strait would have been periodically frozen, thus providing a temporary but passable link (Austin et al., 20 I3) identical to the method Arctic foxes used to reach Iceland during the Little Ice Age (Mellows et al., 20I2).

\section{CONCLUSIONS}

The case studies discussed above demonstrate how DNA retrieved from longdead organisms can shed light on both human-mediated and natural migration processes. The pig data, both in the Pacific and in Europe, demonstrate the complexities of human movement, and the dangers of layering an overly simple explanation upon large spatial and temporal distances. The ability to generate increasing amounts of DNA sequences from archaeological material will 
continue to reveal variability between pig populations in time and space. This increased degree of resolution will only add to our ability to tease apart the complex history of multiple species, and I suspect that within the next decade the domestic animal proxy model for human migration across the Old World will add substantially to our understanding of when and where incoming farmers interacted with indigenous hunter-gatherers (Krause-Kyora et al., 20I3) and what the ramifications were for the humans and for their domestic animal partners.

What we know now at least is that people were likely involved in different degrees of pig domestication across the Old World, and when they migrated these different populations of pigs could easily have mated, creating hybrid populations with hybrid genomes. In fact, hybridisation between indigenous wild populations and introduced domestic populations is common in a wide range of plant and animal species (Larson and Burger, 20I3). For instance, the majority of African cattle are hybrids, demonstrated by the fact that they possess a European (taurine) mitochondrial signal and an Asian (indicine) Y-chromosome signature (Hanotte et al., 2002). Fertile hybrids between other bovid species, including bison, yak, banteng, and gaur, also occur with regularity (Verkaar et al., 2004), and cats (Pierpaoli et al., 2003) and horses (Jordana et al., I995) are known to easily hybridise with a variety of closely related species. This evidence suggests that there is a significant difference between initial domestication processes and subsequent movement and admixture with local wild populations, despite the fact that the latter can result in genetic signatures that are easily misinterpreted as instances of independent domestication. In the case of the Pacific Clade, it is possible that the first pigs introduced to Peninsular Southeast Asia acquired this signature from local wild boar, which was then retained as they were moved by people into the Pacific. This means that modern Polynesian pigs are not necessarily ultimately from Peninsular Southeast Asia, but they at least passed through that region at some stage.

Domestic animals, including pigs, that were associated with early Neolithic farmers often make excellent proxies for the humans who transported them, though during later periods the direct link between animals and humans is less certain owing to trade of animals not necessarily linked with human movement. Having said that, shifts in the frequency and make up of animal genetic haplotypes can be correlated with known demographic shifts lending support to differing hypothesis related to the timing and trajectories of migration routes (e.g., Ottoni et al., 20I3). These associations can be made not just for domestic animals, but also for commensal animals and other species with an association with people. Recent examples include tree snails (Partula hyaline), found across the Pacific, though only the white variety endemic to Tahiti was transported by prehistoric traders between archipelagos, suggesting that the white snails possessed greater aesthetic value for use in jewellery (Lee et al., 2007). 
The geographic patterns of another snail, the Irish Land Snail (Cepaea nemoralis), suggest that they only arrived in Ireland 8,000 years ago when they were transported by Mesolithic hunter-gatherers arriving from the Iberian Peninsula (Grindon and Davison, 2013).

In wild animals, both extant and extinct, aDNA can reveal long-term patterns of genetic turnover (e.g., Brace et al., 20I2), and, along with evidence related to climate change and temporary dispersal bridges, explain not only how non-volant mammals arrived on remote islands, but also when they arrived and how the migration affected the frequencies of haplotypes in modern populations. The advent of new sequencing technologies offers the prospect of both greater numbers of individuals and greater resolution through increased volumes of sequences, thus allowing long-standing questions related to the dispersal of humans and animals to be addressed and answered.

\section{REFERENCES}

Albarella, U., Dobney, K., and Rowley-Conwy, P. 2009. Size and shape of the Eurasian wild boar (Sus scrofa), with a view to the reconstruction of its Holocene history. Environmental Archaeology I4(2): 103-I36.

Albarella, U., Manconi, F., Rowley-Conwy, P., and Vigne, J.D. 2006a. Pigs of Sardinia and Corsica: a biometrical re-evaluation of their status and history. In U. Tecchiati and B. Sala (eds.) Archaeozoological Studies in Honour of Alfredo Riedel. Bolzano: Province of Balzano.

Albarella, U., Tagliacozzo, A., Dobney, K., and Rowley-Conwy, P. 2006b. Pig hunting and husbandry in prehistoric Italy: a contribution to the domestication debate. Proceedings of the Prehistoric Society 72: 193-227.

Allen, M.S., Matisoo-Smith, E., and Horsburgh, A. 200 I. Pacific 'Babes': Issues in the origins and dispersal of Pacific pigs and the potential of mitochondrial DNA analysis. International Journal of Osteoarchaeology I I : 4-I 3 .

Allentoft, M.E., et al. 20I2. The half-life of DNA in bone: measuring decay kinetics in I 58 dated fossils. Proceedings of the Royal Society B: Biological Sciences 279: 4724-4733.

Anderson, A.J. 2005. Crossing the Luzon Strait: Archaeological Chronology in the Batanes Islands, Philippines and the Regional Sequence of Neolithic Dispersal. Journal of Austronesian Studies I: 27-48.

Angerbjörn, A., Hersteinsson, P., and Tannerfeldt, M. 2004a. Arctic Fox. In C. SilleroZubiri, M. Hoffman, and D.W. Macdonald (eds.) Canids: Foxes, Wolves, Jackals and Dogs - Status Survey and Conservation Action Plan. Gland: IUCN.

Angerbjörn, A., Hersteinsson, P., and Tannerfeldt, M. 2004b. Consequences of resource predictability in the Arctic fox - two life history strategies. In D.W. Macdonald and C. Sillero-Zubiri (eds.) The Biology and Conservation of Wild Canids. Oxford: Oxford University Press.

Austin, J.J., et al. 20I3. The origins of the enigmatic Falkland Islands wolf. Nature Communications 4: I 552.

Bellwood, P. 1998. The archaeology of Papuan and Austronesian prehistory in the Northern Moluccas, Eastern Indonesia. In R. Blench and M. Spriggs (eds.) 
Archaeology and Language II: Archaeological Data and Linguistic Hypotheses. London: Routledge.

Bellwood, P. and Diamond, J. 2005. On explicit 'replacement' in Island Southeast Asia: a reply to Stephen Oppenheimer. World Archaeology 37: 503-506.

Bellwood, P. and White, P. 2005. Domesticated pigs in eastern Indonesia. Science 309: $38 \mathrm{I}-38 \mathrm{I}$.

Berta, A. 1987. Origin, diversification, and zoogeography of the South American Canidae Fieldiana. Zoology 39: 455-47I.

Binladen, J., et al. 2006. Assessing the fidelity of ancient DNA sequences amplified from nuclear genes. Genetics I72(2): 733-74I.

Blench, R.M. 2005. From the moutains to the valleys: understanding ethnoliguistic geography in Southeast Asia. In R.M. Blench, L. Sagart, and A. Sanchez-Mazas (eds.) Perspectives on the Phylogeny of East Asian Languages. London: Curzon Press.

Brace, S., et al. 20I2. Serial population extinctions in a small mammal indicate Late Pleistocene ecosystem instability. Proceedings of the National Academy of Sciences I09: 20532-20536.

Bryce, T. 2005. The kingdom of the Hittites. Oxford: Oxford University Press.

Carmichael, L.E., et al. 2007. Historical and ecological determinants of genetic structure in arctic canids. Molecular Ecology I6: $3466-3483$.

Chessa, B., et al. 2009. Revealing the history of sheep domestication using retrovirus integrations. Science 324: 532-536.

Clutton-Brock, J. I999. A Natural History of Domesticated Mammals. Cambridge: Cambridge University Press.

Cucchi, T., Hulme-Beaman, A., and Yuan, J. 20 Io. Early Neolithic pig domestication at Jiahu, Henan Province, China: clues from molar shape analyses using geometric morphometric approaches. Journal of Archaeological Science 38(I): I I-22.

Currat, M., Ruedi, M., Petit, R.J., and Excoffier, L. 2008. The hidden side of invasions: massive introgression by local genes. Evolution 62: I908-I920.

Dalén, L., et al. 2005. Population history and genetic structure of a circumpolar species: the Arctic fox. Biological Journal of the Linnean Society 84: 79-89.

Darwin, C. I 839. Narrative of the surveying voyages of His Majesty's Ships Adventure and Beagle between the years I 826 and I836, describing their examination of the southern shores of South America, and the Beagle's circumnavigation of the globe. London: Henry Colborn.

Diamond, J.M. 2000. Taiwan's gift to the world. Nature 403: 709-710.

Donohue, M. and Denham, T. 20 Iо. Farming and language in Island Southeast Asia. Current Anthropology 5I: 223-256.

Edwards, C.J., Bollongino, R., Scheu, A., Chamberlain, A., Tresset, A., Vigne, J.-D., Baird, J.F. et al. 2007. Mitochondrial DNA analysis shows a Near Eastern Neolithic origin for domestic cattle and no indication of domestication of European aurochs. Proceedings of the Royal Society B: Biological Sciences 274: I377-I385.

Ervynck, A., Dobney, K., Hongo, H., and Meadow, R. 2001. Born free? New evidence for the status of Sus scrofa at Neolithic Çayönü Tepesi (Southeastern Anatolia, Turkey). Paléorient 27: 47-73.

Fernandez, H., et al. 2006. Divergent mtDNA lineages of goats in an Early Neolithic site, far from the initial domestication areas. Proceedings of the National Academy of Sciences I03: I 5375-I5379. 
Flannery, T.F. and White, J.P. I99i. Animal translocation. Research and Exploration 7: $96-\mathrm{II} 3$.

Geffen, E., et al. 2007. Sea ice occurrence predicts genetic isolation in the Arctic fox. Molecular Ecology I6: 424I-4255.

Giuffra, E., Andersson, L., and Nissen, P. 2000. Genetic diversity of eleven European pig breeds. Genetics Selection Evolution 32: I 87-203.

Glover, I. 1986. Archaeology in Eastern Timor 1966-1967, Canberra: ANU.

Gongora, J., et al. 2008. Indo-European and Asian origins for Chilean and Pacific chickens revealed by mtDNA. Proceedings of the National Academy of Sciences I05: I0308-I03 I3.

Green, R.C. 2000. Lapita and the cultural model for intrusion, integration and innovation. In A. Anderson and T. Murray (eds.) Australian Archaeologist Collected Papers in Honour of Jim Allen. Canberra: Coombs Academic Publishing.

Grindon, A.J. and Davison, A. 20I3. Irish Cepaea nemoralis land snails have a cryptic Franco-Iberian origin that is most easily explained by the movements of Mesolithic humans. PLoS ONE 8: e65792.

Grove, J.M. 2003. Little Ice Ages: Ancient and Modern, London: Routledge.

Hanotte, O., Bradley, D.G., Ochieng, J.W., Verjee, Y., Hill, E.W., and Rege, J.E.O. 2002. African pastoralism: genetic imprints of origins and migrations. Science 296: 336-339.

Heinsohn, T. 2003. Animal translocation: long-term human influences on the vertebrate zoogeography of Australasia (natural dispersal versus ethnophoresy). Zoologist 32: $35 \mathrm{I}-376$.

Hersteinsson, P. 20Io. Íslenska tófan. Veididagbok 20Io. Reykjavik: Environmental Agency of Iceland.

Hersteinsson, P., Angerbjörn, A., Frafjord, K., and Kaikusalo, A. I989. The Arctic Fox in Fennoscandia and Iceland: management problems. Biological Conservation 49: $67-8 \mathrm{I}$.

Hersteinsson, P., Nyström, V., Jóhannsson, J.H., Guðjónsdóttir, B., and Hallsdóttir, M. 2007. Elstu Dekktu Leifar Melrakka á íslandi. Náttúrufræðingurinn 76: I3-2I.

Higham, C.F.W. 1975. Aspects of economy and ritual in Prehistoric Northeast Thailand. Journal of Archaeological Science 2: 245-288.

Higham, C.F.W. 2002. Early Culture of Mainland Southeast Asia. Bangkok: River Books.

Hongo, H. and Meadow, R. I998. Pig exploitation at Neolithic Cayonu Tepesi (Southeastern Anatolia). In S.M. Nelson (ed.) Ancestors for the Pigs: Pigs in Prehistory. Penn press.

Hurles, M.E., Matisoo-Smith, E., Gray, R.D., and Penny, D. 2003. Untangling Oceanic settlement: the edge of the knowable. Trends in Ecology \& Evolution I 8: 53 I-540.

Jordana, J., Pares, P.M., and Sanchez, A. I995. Analysis of genetic relationships in horse breeds. Journal of Equine Veterinary Science I 5: 320-328.

Kirch, P.V. 2000. On the Road of the Winds: An Archaeological History of the Pacific Islands before European Contact. Berkeley: University of California Press.

Krause-Kyora, B., Makarewicz, C., Evin, A., Flink, L.G., Dobney, K., Larson, G., Hartz, S., et al. 2013. Use of domesticated pigs by Mesolithic hunter-gatherers in northwestern Europe. Nature Communications 4 (2348). 
Larson, G. and Burger, J. 20I3. A population genetics view of animal domestication. Trends in Genetics 29(4): I97-205.

Larson, G., Albarella, U., Dobney, K., Rowley-Conwy, P., Schibler, J., Tresset, A., Vigne, J.-D., et al. 2007a. Ancient DNA, pig domestication, and the spread of the Neolithic into Europe. Proceedings of the National Academy of Sciences I04: I $5276-$ I 528 I.

Larson, G., Cucchi, T., Fujita, M., Matisoo-Smith, E., Robins, J., Anderson, A., Rolett, B., et al. 2007b. Phylogeny and ancient DNA of Sus provides insights into neolithic expansion in island southeast Asia and Oceania. Proceedings of the National Academy of Sciences I04: 4834-4839.

Larson, G., Dobney, K., Albarella, U., Fang, M., Matisoo-Smith, E., Robins, J., Lowden, S., et al. 2005. Worldwide phylogeography of wild boar reveals multiple centers of pig domestication. Science 307: I6I8-I62I.

Larson, G., Liu, R., Zhao, X., Yuan, J., Fuller, D., Barton, L., Dobney, K., et al. 2 o Io. Patterns of East Asian pig domestication, migration, and turnover revealed by modern and ancient DNA. Proceedings of the National Academy of Sciences I07: 7686-769I.

Lee, T., Burch, J.B., Coote, T., Fontaine, B., Gargominy, O., Pearce-Kelly, P., and Foighil, D.Ó. 2007. Prehistoric inter-archipelago trading of Polynesian tree snails leaves a conservation legacy. Proceedings of the Royal Society B: Biological Sciences 274: 2907-29I4.

Luetkemeier, E., Sodhi, M., Schook, L.B., and Malhi, R.S. 20ı. Multiple Asian pig origins revealed through genomic analyses. Molecular Phylogenetics and Evolution 54: 680-686.

Mann, M.E. 2002. Little Ice Age. In M.C. Maccracken and J.S. Perry (eds.) Encyclopedia of Global Environmental Change. Chichester: Wiley.

Matisoo-Smith, E. and Robins, J.H. 2004. Origins and dispersals of Pacific peoples: Evidence from mtDNA phylogenies of the Pacific rat. Proceedings of the National Academy of Sciences IOI: 9I67-9I72.

Mellows, A., Barnett, R., Dalén, L., Sandoval-Castellanos, E., Linderholm, A., McGovern, T.H., Church, M.J., and Larson, G. 20I2. The impact of past climate change on genetic variation and population connectivity in the Icelandic Arctic fox. Proceedings of the Royal Society B: Biological Sciences 279 (I747): 4568-4573.

Morwood, M.J., Morwood, Soejono, R.P., Roberts, R.G., Sutikna, T., Turney, C.S.M., Westaway, K.E., Rink, W.J., et al. 2004. Archaeology and age of a new hominin from Flores in eastern Indonesia. Nature 43 I: I087-I09I.

Norén, K., Angerbjörn, A., and Hersteinsson, P. 2009a. Population structure in an isolated Arctic fox, Vulpes lagopus, population: the impact of geographical barriers. Biological Journal of the Linnean Society 97: i 8-26.

Norén, K., Carmichael, L., Dalén, L., Hersteinsson, P., Samelius, G., Fuglei, E., and Kapel, C.M.O., et al. 20 IO. Arctic fox Vulpes lagopus population structure: circumpolar patterns and processes. Oikos I20: $873-885$.

Norén, K., Carmichael, L., Fuglei, E., Eide, N.E., Hersteinsson, P., and Angerbjörn, A. 20 I I. Pulses of movement across the sea ice: population connectivity and temporal genetic structure in the Arctic fox. Oecologia I66: 973-984.

Norén, K., Dalén, L., Kvaløy, K., and Angerbjörn, A. 2005. Detection of farm fox and hybrid genotypes among wild Arctic foxes in Scandinavia. Conservation Genetics 6: $885-894$. 
Norén, K., Kvaløy, K., Nyström, V., Landa, A., Dalén, L., Eide, N.E., Østbye, E., et al. 2009b. Farmed Arctic foxes on the Fennoscandian mountain tundra: implications for conservation. Animal Conservation I2: 434-444.

Ogilvie, A.E.J. I99I. Climatic changes in Iceland AD c. 865 to I 598, in the Norse of the North Atlantic. Acta Archaeology 6I: 233-25I.

Oppenheimer, S. 2004. The 'Express Train from Taiwan to Polynesia': on the congruence of proxy lines of evidence. World Archaeology 36: 59 I-600.

Ottoni, C., Flink, L.G., Evin, A., Geörg, C., De Cupere, B., Van Neer, W., Bartosiewicz, L., et al. 20I3. Pig domestication and human-mediated dispersal in western Eurasia revealed through ancient DNA and geometric morphometrics. Molecular Biology and Evolution 30: 824-832.

Pamperin, N.J., Follmann, E.H., and Person, B.T. 2008. Sea ice use by Arctic foxes in northern Alaska. Polar Biology 3 I: I42 I-I 426.

Pawley, A. 2003. The Austronesian dispersal: languages, technologies and people. In C. Renfrew and P. Bellwood (eds.) Examining the Farming/Language Dispersal Hypothesis. Cambridge: McDonald Institute for Archaeological Research.

Pierpaoli, M., Birò, Z.S., Herrmann, M., Hupe, K., Fernandes, M., Ragni, B., Szemethy, L., and Randi, E. 2003. Genetic distinction of wildcat (Felis silvestris) populations in Europe, and hybridization with domestic cats in Hungary. Molecular Ecology I2: 2585-2598.

Piper, P.J., Hung, H., Campos, F.Z., Bellwood, P., and Santiago, R. 2009. A 4000 year-old introduction of domestic pigs into the Philippine Archipelago: implications for understanding routes of human migration through Island Southeast Asia and Wallacea. Antiquity 83: 687-695.

Ramírez, O., Ojeda, A., Tomàs, A., Gallardo, D., Huang, L.S., Folch, J.M., Clop, A., et al. 2009. Integrating Y-chromosome, mitochondrial, and autosomal data to analyze the origin of pig breeds. Molecular Biology and Evolution 26: 206I.

Seeher, J. 20I I. The plateau: the Hittites. In S.R. Steadman and J.G. Mcmahon (eds.) The Oxford Handbook of Ancient Anatolia: Io,ooo-323 BCE. New York: Oxford University Press.

Shapiro, B. and Hofreiter, M. (eds.) 20I2. Ancient DNA: Methods and Protocols. New York: Springer.

Slater, G.J., Thalmann, O., Leonard, J.A., Schweizer, R.M., Koepfli, K.-P., Pollinger, J.P., Rawlence N.J., et al. 2009. Evolutionary history of the Falklands wolf. Current Biology I9: R937-R938.

Spriggs, M.J.T. I997. The Island Melanesians, Cambridge: Blackwell.

Tannerfeldt, M. and Angerbjörn, A. 1996. Life history strategies in a fluctuating environment: establishment and reproductive success in the Arctic fox. Ecography I9: $209-220$.

Tarroux, A., Berteaux, D., and Bêty, J. 20ıo. Northern nomads: ability for extensive movements in adult Arctic foxes. Polar Biology 33: IO2 I-IO26.

Terrell, J.E., Kelly, K.M., and Rainbird, P. 200I. Foregone conclusions? In search of 'Papuans' and 'Austronesians'. Current Anthropology 42: 97-I24.

Van Driem, G. I998. Neolithic correlates of ancient Tibeto-Burman migrations. In R. Blench and M. Spriggs (eds.) Archaeology and Language II: Archaeological Data and Linguistic Hypotheses. London: Routledge. 
Verkaar, E.L.C., Nijman, I.J., Beeke, M., Hanekamp, E., and Lenstra, J.A. 2004. Maternal and paternal lineages in cross-breeding bovine species. Has wisent a hybrid origin? Molecular Biology and Evolution 21: I I65-I I 70.

Vinnikov, K.Y., Robock, A., Stouffer, R.J., Walsh, J.E., Parkinson, C.L., Cavalieri, D.J., Mitchell, J.F.B., et al. I999. Global warming and northern hemisphere sea ice extent. Science 286: I934-I937.

Wilmshurst, J.M., Hunt, T.L., Lipo, C.P., and Anderson, A.J. 20I I. High-precision radiocarbon dating shows recent and rapid initial human colonization of East Polynesia. Proceedings of the National Academy of Sciences I08: I8 I 5-I 820.

Wollstein, A., Lao, O., Becker, C., Brauer, S., Trent, R.J., Nürnberg, P., Stoneking, M., and Kayser, M. 20Io. Demographic history of Oceania inferred from genome-wide data. Current Biology 20: 1983-1992.

Wu, C.Y., Jiang, Y.N., Chu, H.P., Li, S.H., Wang, Y., Li, Y.H., Chang, Y., and Ju, Y.T. 2007. The type I Lanyu pig has a maternal genetic lineage distinct from Asian and European pigs. Animal Genetics. 38: 499-505. 